\title{
Environmental health indicator for the evaluation of neighborhoods in urban areas: a case study in Caruaru (PE), Brazil
}

Indicador de salubridade ambiental para avaliação de bairros em áreas urbanas: um estudo de caso em Caruaru (PE), Brasil

\author{
Armando Dias Duarte $^{1}$ (D), Saulo de Tarso Marques Bezerra ${ }^{1}$ (D), Elizabeth Amaral Pastich Gonçalves ${ }^{1}$ (i)
}

\section{A B S T RAC T}

The environment, over the years, has been subjected to strong negative impacts caused byeconomic policies that have promoted an uncontrolled growth of urbanization in the cities and abusive exploration of the natural resources. In this context, developing socio-environmental indicators to subsidize the formulation of municipal public policies which consider, specifically, the environmental (in)salubrity of each neighborhood or locality of municipalities is imperative. The present paper presents the construction and application of an environmental health indicator for residential neighborhoods in two localities of Caruaru City, Pernambuco State. The data adopted in research were obtained from databases of City Hall institutions, from interviews with the population of the localities and water quality analyses. The results indicated that the neighborhoods analyzed presented characteristics of medium health; water supply, the disposal of solid waste, and socioeconomic aspects require attention and priority of public policies. In conclusion, the proposed indicator can be an instrument to assist in urban planning and environmental management of Brazilian municipalities, because it can guide the performance of public managers and the civil society to identify priority actions for improving the infrastructure of the most unhealthy neighborhoods.

Keywords: healthiness; environmental health; environmental sanitation; environmental management; environmental health indicator.

\section{RE S U M 0}

Omeio ambiente, ao longo dos anos, tem sido submetido a fortes impactos negativos gerados por políticas econômicas que impulsionaram um processo desordenado de urbanização das cidades e exploração abusiva dos recursos naturais. Nesse contexto, é imperativo o desenvolvimento de indicadores socioambientais para subsidiarem a formulação de políticas públicas municipais que considerem, especificamente, a (in) salubridade ambiental de cada bairro ou localidade dos municípios. Este trabalho apresenta a construção e aplicação de um indicador de salubridade ambiental para bairros residenciais em duas localidades de Caruaru, Pernambuco. Os dados adotados nesta pesquisa foram obtidos por meio de bancos de dados de órgãos da prefeitura municipal, de entrevistas à população das localidades e de análises da qualidade da água. Os resultados apontaram que os bairros analisados apresentaram características de média salubridade, onde foi identificado que o abastecimento de água, a disposição de resíduos sólidos e os aspectos socioeconômicos necessitam de uma maior atenção e prioridade das políticas públicas. Conclui-se que o indicador proposto pode ser um instrumento para auxiliar o planejamento urbano e a gestão ambiental dos municípios brasileiros, uma vez que pode balizar a atuação de gestores públicos e da sociedade civil na identificação de ações prioritárias para a melhoria da infraestrutura dos bairros mais insalubres.

Palavras-chave: salubridade; salubridade ambiental; saneamento ambiental; gestão ambiental; indicador de salubridade ambiental.

${ }^{1}$ Universidade Federal de Pernambuco - Recife (PE), Brazil.

Correspondence address: Saulo de Tarso Marques Bezerra - Avenida Marielle Franco, s/n, Km 59 - Nova Caruaru - CEP: 55014-900 - Caruaru

(PE), Brazil - E-mail: s.bezerra@yahoo.com.br

Conflicts of interest: the authors declare that they have no conflicts of interest.

Funding: This study was financially supported by the Foundation for the Support of Science and Technology of Pernambuco (Fundação de Amparo à Ciência e Tecnologia de Pernambuco, FACEPE) (Brazil) [process IBPG-0779-3.01/16] and Coordenação de Aperfeiçoamento de Pessoal de Nível Superior (CAPES) (Brazil) [Finance Code 001].

Received on: 04/10/2020. Accepted on: 09/29/2020

https://doi.org/10.5327/Z21769478750 


\section{Introduction}

Today, around half of people live in urban areas worldwide, and this ratio is estimated to increase to two out of three people by 2050 . Although the growth of urban population over the $20^{\text {th }}$ century occurred on a small portion of the global Earth surface $(<3 \%)$, the impact has been significant, with $78 \%$ of the carbon emissions, $60 \%$ of the use of residential water, and $76 \%$ of the wood used for industrial purposes attributed to the cities (LUCK; WU, 2002; WU et al., 2011). According to the World Health Organization (WHO), in its report on the Joint Monitoring Program in 2015 (WHO, 2015), 21\% of the world population do not use safe water services (free from contamination), and $11 \%$ of the global population do not access basic drinking water services.

In Brazil, the environment has been subjected to strong negative impacts caused by economic policies, which promoted an uncontrolled urbanization process in the cities and abusive exploration of their natural resources. This process, a result from the absence of efficient public policies, generated a deficit in housing and services, causing the formation of peripheries occupied in a precarious and illegal way by urban workers, who have been attracted to cities that were not prepared for this migratory flow.

The process of urban concentration occurred mostly because of the migratory flow of field workers and their families to city peripheries, attracted by the hope of a higher quality of life, especially regarding the availability of jobs, education, and health. Nevertheless, given the cities were not prepared to receive this contingent in most cases, the integration of these people into the urban space was developed anomalously. This fact derived mainly from the speed of the process itself and by the precariousness of the urban equipment, especially in the peripheral regions of the cities.

The public power faces the challenge of prioritizing the formulation of socio-environmental public policies which adopt clean technologies, aimed at sustainable consumption, selective collection, recycling, and reduction of waste in public and private activities (BELIZÁRIO, 2012). Therefore, public policies must prioritize the environmental health of the population. Environmental health is directly related to sanitation services, appropriate housing conditions, and the existence of proper socioeconomic policies. The relation between sanitation and health is narrow; according to Law No. 11.445, which establishes the guidelines for basic sanitation in Brazil, public sanitation services are provided according to the environmental principles of waste collection and disposal of sewage (BRASIL, 2007). The concept of environmental health can be defined as the environmental quality required to prevent diseases transmitted by the environment and promote the improvement of mesological conditions favorable to the health of both the urban and rural population (CONESAN, 1999).

Brazilian investments in sanitation services and water resources are insufficient to guarantee good health conditions in a large number of cities. In this case, the adoption of criteria directed to establish- ing priorities for the application of the available resources, aiming at maximizing the benefits, is needed. For this, adopting efficient tools of easy application is important. The topic demands that the studies and planning of actions, both preventive and corrective, be based on reality to involve the direct and indirect actors in the analysis process. Mechanisms must be proposed to measure the health conditions of the environment, direct actions compatible with the existing reality, and contribute to define priorities in the process of public power decision and investments, especially in sanitation services.

The use of indicators and management tools contribute to the development of the functions which aim at guiding and aggregating information about the reality, so that the environmental, physical, and social aspects can be incorporated for assistance in tracking sustainable progress. In the world, the most popular among the environmental indicator systems is PSR (Pressure-State-Response). The model was developed and originally recommended by the Organization for Economic Cooperation and Development (OECD, 1993). This approach is an expanded version of the PSR model, which has been used by the United Nations Environment Programme (UNEP) on the elaboration of the series Global Environment Outlook (GEO). This project started in 1995 and aims at evaluating the conditions of the environment at the global, regional, and national levels (TAYRA; RIBEIRO, 2006).

Among the socio-environmental indicators available in Brazil, the Environmental Health Indicator (Indicador de Salubridade Ambiental, EHI) must be highlighted, which evaluates the services from the sanitation sector and the socioeconomic conditions of the population. The evolution of EHI over the years has been considered positive for the Brazilian technical-scientific community, and enabled the insertion and adaptation of new indicators to the original model. In this context, research by Teixeira, Prado Filho and Santiago (2018) is prominent, who identified 60 publications which adopted EHI for the evaluation of environmental health at different localities, such as: the cities of Criciúma (Santa Catarina State) (VALVASSORI; ALEXANDRE, 2012) and Mossoró (Rio Grande do Norte State) (PEIXOTO et al., 2018), the neighborhood of Gargaú, in São Francisco do Itabopoana City (Rio de Janeiro State) (SANTOS; FERREIRA, 2016), and the river basin of the stream Reginaldo in Maceió City (Alagoas State) (SILVA et al., 2017).

Improper occupation of soil can also increase the vulnerability of individuals and communities in relation to natural catastrophes (SANTOS; FORMIGA; FERREIRA, 2020). In this context, Bosco, Cardoso and Young (2019) evaluated the socio-environmental vulnerability to the occurrence of landslides in an area of the Metropolitan Region of Vale do Paraíba, São Paulo State, with the construction of a synthetic index of environmental and socioeconomic scope. The results showed an extremely high overall vulnerability index in the regions of Campos do Jordão and Natividade da Serra.

In this context, developing socio-environmental indicators to subsidize the formulation of municipal public policies which consider, 
specifically, the environmental (un)health of each neighborhood in the municipality is imperative. The present paper presents the construction and application of the Environmental Health Indicator for Residential Neighborhoods (EHIN) in two localities of Caruaru City (Pernambuco State), Brazil. EHIN is a tool to assist urban planning and environmental management of municipalities, because it can guide the performance of public managers and the civil community on the identification of priority actions for improving the infrastructure of the unhealthiest neighborhoods. The indicator proposed is expected to be adopted at different localities, given its required information is of easy acquisition and applicability.

\section{Environmental Health Indicators}

In 1999, the group of specialists that composed CONESAN/SP developed the Environmental Health Indicator (EHI) to evaluate the socio-environmental conditions of the population. The original composition of EHI is given by Equation 1, and its final score varies from 0 to 1.

$$
\begin{aligned}
& \mathrm{EHI}=0.25 \mathrm{IWS}+0.25 \mathrm{ISS}+0.25 \mathrm{ISW} \\
& +0.10 \mathrm{ICV}+0.10 \mathrm{WRI}+0.05 \mathrm{SEI}
\end{aligned}
$$

In which:

IWS = Indicator for Water Supply;

ISS = Indicator for Sanitary Sewage;

ISW = Indicator for Solid Waste;

$\mathrm{ICV}=$ Indicator for the Control of Vectors;

$\mathrm{WRI}=$ Water Resources Indicator;

$\mathrm{SEI}=$ Socioeconomic Indicator.

Every first-order indicator is calculated based on associated sub-indicators (second-order indicators). The Basic Manual of EHI (CONESAN, 1999) does not establish the level of environmental health of the study place in relation to the indicator's score range. Most of the technical-scientific works adopt the values established by Dias, Borja and Moraes (2006) in the literature (Table 1). The indicators are determined by a qualitative and quantitative analysis of specific socio-environmental aspects, especially those related to environmental sanitation, with values varying from 0 to 1. The closest to the superior value, the highest the environmental health.

The variables choice by CONESAN was established according to the following principles:

- uniformity of the database and criteria and ways of calculation;

- possibility of comparison among the municipalities, which, in terms of sanitation, is limited to water supply, sanitary sewage and urban cleaning. The socioeconomic conditions are expressed by the parameters assessed by each state, related to public health aspects, income, and education. Nonetheless, for the identification of extensive or localized aspects, which differ according to the region, the comparison of EHI must be associated to the respective EHI adopted, whose variables must be in agreement;
- possibility of attributing adjusted weights to the aspects of the previous item;

- the need to limit data and information to be used, which must be available and easily tabulated.

Teixeira, Prado Filho and Santiago (2018) identified 60 publications with the use of EHI in different areas and urban occupations, with the Southern (20) and Northeastern regions (19) of the country representing the greatest numbers of studies on this topic. Research claims that unifying one EHI all over Brazil is a challenge, given the local specificities and difficulties in obtaining data from public agencies (secretariats, authorities etc.), whose reliability may be questionable. Aiming to overcome this challenge, present work proposes an easily applicable indicator, which can be adopted in other places, since it does not depend on governmental data.

Valvassori and Alexandre (2012) adapted EHI to evaluate the environmental health of urban areas in Criciúma City. The study results indicated a water supply index with good indicatives, varying from 0.8 to 1 , whereas urban drainage and sanitary sewage require greater attention of the public power. Santos and Ferreira (2016) also adopted EHI as a basis to analyze the neighborhood of Gargaú in São Francisco do Itabopoana City, located near the mouth of the Paraíba do Sul river, thus adapting the model to an estuarine ecosystem. This locality is known by its important mangroves; the main income of the local population comes from the collection of crabs, shellfish, and fish. From the comparisons of results of the bacteriological and physicochemical analyses of the underground water quality with the maximum values allowed for human consumption, the community presented an unhealthy environment that needed combined actions from both the community and the public power.

Silva et al. (2017) developed a study in the basin of the stream Reginaldo in Maceió City, aiming at the correlation of incidence of waterborne diseases with EHI. The results indicated a correlation between EHI and the incidence of the diseases Dengue Fever, Hepatitis, and Leptospirosis. Mari et al. (2019) determined the EHI for municipalities of the Paraná III river basin. The data used for calculating the EHI were obtained from field surveys and research in governmental databases. As a result, defining that most of the bordering and non-bordering municipalities in the region were defined as presenting healthy conditions.

Table 1 - Environmental health level in relation to EHI score range.

\begin{tabular}{|c|c|}
\hline Health level & Score \\
\hline Insalubrity & $0-25$ \\
\hline Low salubrity & $26-50$ \\
\hline Medium salubrity & $51-75$ \\
\hline Healthy & $76-100$ \\
\hline
\end{tabular}

Source: Dias, Borja and Moraes (2006). 
Kobren et al. (2019) applied EHI in Porto Rico City (Paraná State), to characterize the potentialities and failures related to the elements which compose the indicator. The results obtained indicated the municipal health as satisfactory. Nevertheless, the global assessment does not rule out specific problems, such as the deficiency in controlling the transmitting vector of Dengue Fever and the possible future problem of water availability to supply the population.

Rocha, Rufino and Barros Filho (2019) evaluated the health conditions of Campina Grande City (Paraíba State) using an adaptation of EHI. The values of EHI/CG were associated to the census sectors of the district-headquarters of the municipality to allow, initially, an analysis of the spatial distribution of its values in the city. Santos, Formiga and Ferreira (2020) correlated socio-environmental vulnerability indicators in Goiás State with the urban drainage system. For developing indicators, the technique of exploratory factor analysis was employed. The three indicators developed (environmental fragility, infrastructural quality, and social quality) were aggregated into a single indicator. The data sets made available for the analyzes developed in research refer to the results of the 2010 Population Census by the Brazilian Institute of Geography and Statistics (Instituto Brasileiro de Geografia e Estatística, IBGE). The results demonstrated that sectors with better drainage systems (higher proportions of households with manhole and curb) tend to present higher indicators of social and infrastructural quality, and lower values of environmental fragility.

Several studies have presented models for socio-environmental evaluation which aggregate the use of geographic information systems (GIS) (LI; WENG, 2007; PADILLA et al., 2016; MUSSE; BARONA; RODRIGUEZ, 2018; PEIXOTO et al., 2018). Li and Weng (2007) developed a methodology to integrate the remote sensing data and the demographic census performed in the United States in a GIS platform to compose a quality of life index. The study was conducted in the urban area of Marion County (Indianapolis), Indiana. The authors extracted variables from socioeconomic information obtained from data from the 2000 census and aimed at integrating the data to the Landsat Enhanced Thematic Mapper Plus (ETM+) satellite images. The index was developed from the combination of three factors, which represent different aspects of quality of life. The researchers concluded that the indicative proposed needs an incorporation of other dimensions and the combination of objective and subjective aspects.

Musse, Barona and Rodriguez (2018) presented a quantitative approach to evaluate the environment of the urban area of Cali City, Colombia, by adding more variables to the model proposed by $\mathrm{Li}$ and Weng (2007). The authors concluded that the environmental and socioeconomic conditions of the neighborhoods in Cali are highly correlated, which indicates that the environmental quality depends on the income capacity of the population and on urban structure, a fact observed in several cities of Latin America.

Padilla et al. (2016) conducted a study in Nice City, France, to identify how socioeconomic factors, such as access to health, and cu- mulative factors in small urban areas interfere in the inequalities and environmental health, and what is their correlation with infant and neonatal mortality. The work presented indicators for privation, proximity to high traffic roads, green spaces, and accessibility to health, by GIS. The results showed that the poorest population has a higher risk of neonatal mortality and is exposed to more air pollution, because of the approximation of high traffic roads.

Peixoto et al. (2018) characterized the situation of environmental sanitation of Mossoró City (Rio Grande do Norte State). For this, an EHI composed of three sub-indices was applied, with the support of a GIS: water supply, garbage collection, and sanitary sewage treatment. The study showed that there is a spatial concentration in the access to sanitation services, and sewage treatment was the most sensitive for the indicator.

When the main contributions regarding the use of socio-environmental indicators are evaluated, information sharing has a common goal, the metric of impacts on the environment and health, derived from human activities. In this sense, the contribution of each strategy adopted, both national and international, is valuable to measure these impacts and identify sectors which require major interventions to promote population health, well-being, and citizenship.

\section{Materials and Methods}

\section{Study area}

Caruaru City, located in the mesoregion of Vale do Ipojuca, encompasses a territorial area of $921 \mathrm{~km}^{2}$, representing $0.94 \%$ of the area of Pernambuco State (Figure 1). It had a resident population of 351,686 inhabitants in 2016 (IBGE, 2017). According to the Municipal Human Development Index (MHDI), published in the Atlas of Human Development in Brazil in 2010, the city presented an MHDI of 0.677 .

Caruaru is in the Brazilian semi-arid region and is placed within the domains of the basins of both Ipojuca and Capibaribe rivers, whose main tributaries are: Capibaribe river and the streams Tabocas, Caiçara, Borba, da Onça, Olho d’Água, Mandacaru do Norte, Carapotós, São Bento, Curtume, and Taquara. All water courses in the municipality have intermittent flow regime, and their drainage pattern is dendritic. The main reservoirs responsible for city supply are Jucazinho and Prata. The Prata reservoir is in Bonito City (Pernambuco State) and has a capacity of 42 million cubic meters.

Given the water crisis of the region, the population often uses the water provided by trucks, which transport containers with capacity of 1,000 liters, and tank trucks. The water provided by tank trucks may be inappropriate for human consumption. The study performed by Mendonça et al. (2017) indicated that the water provided in Caruaru has low potability index and high risk of contamination by pathogens (presence of the thermotolerant coliform Pseudomonas aeroginosa and high numbers of heterotrophic bacteria). 
The neighborhoods evaluated belong to the urban area of Caruaru and were chosen based on the number of confirmed cases of Dengue Fever and Chikungunya, from 2015 to 2017. Data were obtained from the Management of Work Operation and Health Education from the City Hall (Gerência de Gestão do Trabalho e Educação em Saúde da Prefeitura Municipal) (PREFEITURA DE CARUARU, 2018a), and indicated neighborhoods $A$ and $B$ for having more cases of arboviruses. Given the nature of the topic addressed, omitting the names of the neighborhoods evaluated was a decision.

\section{Environmental health indicator for neighborhoods}

Given the need for adaptation of the EHI to the context of the Agreste region of Pernambuco State and application on the scale of neighborhood, a new indicator is proposed, named Environmental Health Indicator for Neighborhoods (EHIN), from the adaptation of the original model proposed by CONESAN (1999). The first-order indicator of EHI related to water resources (WRI) was excluded, because the evaluation of springs is not applicable at the neighborhood scale. The definition of weights and first-order indicators was performed based on Barreto et al. (2020), who affirmed, based on literature review (48 works published from 1999 to 2019), that states that the distribution of weights can be the same adopted by the original model; consultation with experts in the field (application of the Delphi method) was also used. In this sense, the original values of the weights of the first four first-order indicators were maintained, and the redistribution of the weight of the WRI to the socioeconomic indicator (SEI) was made, considering that the indicator SEI was underestimated in the original EHI.

EHIN was calculated by Equation 2 and has its composition according to Table 2.

$$
\mathrm{EHIN}=0.25 \mathrm{IWS}+0.25 \mathrm{ISS}+0.25 \mathrm{ISW}+0.10 \mathrm{ICV}+0.15 \mathrm{SEI}
$$

In which:

$$
\begin{aligned}
& \text { IWS = Indicator for Water Supply; } \\
& \text { ISS = Indicator for Sanitary Sewage; } \\
& \text { ISW = Indicator for Solid Waste; } \\
& \text { ICV = Indicator for the Control of Vectors; } \\
& \text { SEI = Socioeconomic Indicator. }
\end{aligned}
$$

Second-order indicators were defined based on specialized literature, with adaptations and modifications being performed according to consultations with specialists of the specific area. The changes were defined aiming at the applicability on a neighborhood scale and easiness of implementation. Except for the water quality index (WQI), which is defined by laboratory analyses, all information was obtained in interviews with the population and visits in loco. Thus, the application of the proposed model can be easily performed in other areas and/or

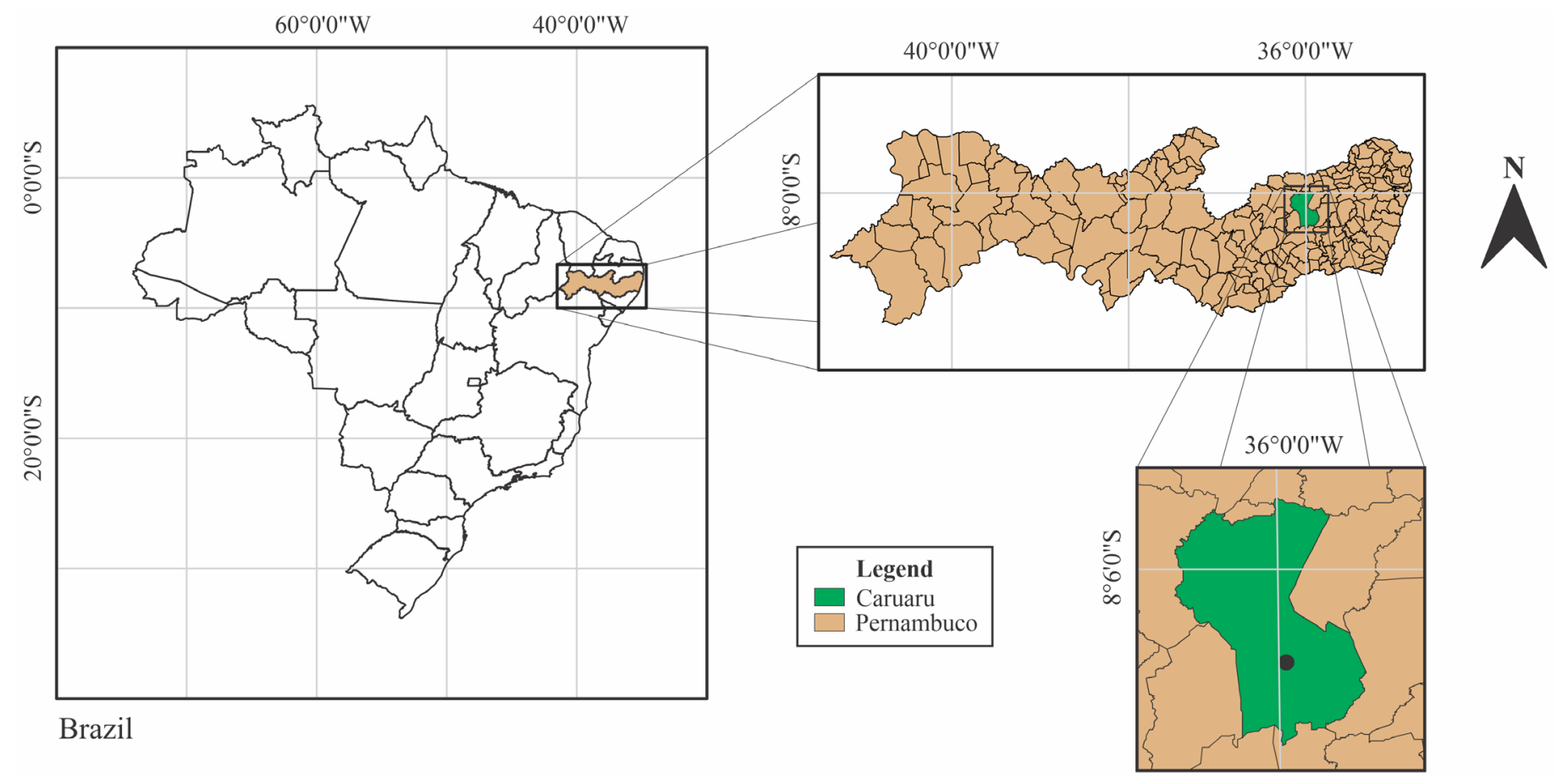

Figure 1 - Location of Caruaru City, Pernambuco State. 
Table 2 - Composition of the indicator EHIN for Caruaru City, Pernambuco State.

\begin{tabular}{|c|c|c|c|c|}
\hline $\begin{array}{l}1^{\text {st }} \text { order } \\
\text { indicator }\end{array}$ & $\begin{array}{l}\text { Calculation of the } \\
1^{\text {st }} \text { order indicator }\end{array}$ & $2^{\text {nd }}$ order indicator & Goal of the $2^{\text {nd }}$ order indicator & Score value \\
\hline \multirow{3}{*}{$\begin{array}{l}\text { Indicator for water } \\
\text { supply - } \\
\text { IWS }\end{array}$} & \multirow[b]{3}{*}{$\begin{array}{c}\mathrm{IWS}=(\mathrm{SCI}+\mathrm{WRI}+ \\
\mathrm{WQI}) / 3\end{array}$} & $\begin{array}{c}\text { SCI }=\text { service coverage } \\
\text { index }\end{array}$ & $\begin{array}{l}\text { To identify whether the household is assisted by } \\
\text { a supply network }\end{array}$ & $\begin{array}{c}\text { Always }=1 \\
\text { Sometimes }=0.5 \\
\text { Never }=0\end{array}$ \\
\hline & & $\mathbf{W R I}=$ water reuse index & To identify whether the household reuses water & $\begin{array}{l}\text { Yes }=1 \\
\text { No }=0\end{array}$ \\
\hline & & WQI = water quality index & $\begin{array}{l}\text { To verify, by laboratory analyses, the percentage } \\
\text { of households in which water sample is } \\
\text { considered potable based on colimetry, } \\
\text { chlorine, and turbidity. }\end{array}$ & $\begin{array}{c}\text { WQI }=100 \% \rightarrow 1 \\
100 \%>\text { WQI } \geq 95 \% \rightarrow 0.8 \\
95 \%>\text { WQI } \geq 85 \% \rightarrow 0.6 \\
85 \%>\text { WQI } \geq 70 \% \rightarrow 0.4 \\
70 \%>\text { WQI } \geq 50 \% \rightarrow 0.2 \\
\text { WQI }<50 \% \rightarrow 0\end{array}$ \\
\hline \multirow{2}{*}{$\begin{array}{l}\text { Indicator for } \\
\text { sanitary sewage } \\
\text { - ISS }\end{array}$} & \multirow[t]{2}{*}{$\mathrm{ISS}=(\mathrm{SDI}+\mathrm{OSI}) / 2$} & $\begin{array}{c}\text { SDI = sewage destination } \\
\text { index }\end{array}$ & $\begin{array}{l}\text { To identify whether the household is connected } \\
\text { to the sewage network }\end{array}$ & $\begin{array}{c}\text { Network }=1 \\
\text { Septic } \operatorname{tank}=0.5 \\
\text { Others }=0\end{array}$ \\
\hline & & OSI = open sewage index & $\begin{array}{l}\text { To verify whether there are places with the } \\
\text { presence of open sewage }\end{array}$ & $\begin{array}{l}\text { Yes }=0 \\
\text { No }=1\end{array}$ \\
\hline \multirow{4}{*}{$\begin{array}{l}\text { Indicator for solid } \\
\text { waste - ISW }\end{array}$} & \multirow{4}{*}{$\begin{array}{c}\mathrm{ISW}=(\mathrm{WCI}+\mathrm{SSI}+ \\
\mathrm{WSI}+\mathrm{WDI}) / 4\end{array}$} & $\begin{array}{c}\text { WCI = waste collection } \\
\text { index }\end{array}$ & $\begin{array}{l}\text { To identify waste collection in the } \\
\text { neighborhood }\end{array}$ & $\begin{array}{l}\geq 3 \text { collections per week }=1 \\
\qquad \begin{array}{c}\text { Weekly }=0.5 \\
\text { Rare }=0.3 \\
\text { Never }=0\end{array}\end{array}$ \\
\hline & & $\begin{array}{c}\text { SSI }=\text { street sweeping } \\
\text { index }\end{array}$ & To identify sweeping in the locality & $\begin{array}{c}\geq 3 \text { sweepings per week }=1 \\
\text { Weekly }=0.5 \\
\text { Rare }=0.3 \\
\text { Never }=0\end{array}$ \\
\hline & & $\begin{array}{c}\text { WSI }=\text { waste separation } \\
\text { index }\end{array}$ & $\begin{array}{c}\text { To identify whether the household performs } \\
\text { waste separation }\end{array}$ & $\begin{array}{c}\text { Yes }=1 \\
\text { No }=0 \\
\text { No selective collection }=0\end{array}$ \\
\hline & & $\begin{aligned} \text { WDI }= & \text { waste disposal } \\
& \text { index }\end{aligned}$ & $\begin{array}{l}\text { To identify where the waste is disposed for } \\
\text { collection }\end{array}$ & $\begin{array}{c}\text { Floor }=0 \\
\text { Collection point }=0.5 \\
\text { Bin }=1\end{array}$ \\
\hline \multirow{4}{*}{$\begin{array}{l}\text { Indicator for the } \\
\text { control of vectors - } \\
\text { ICV }\end{array}$} & \multirow{4}{*}{$\begin{array}{l}\mathrm{ICV}=(\mathrm{IPD}+\mathrm{ICF}+ \\
\mathrm{IPR}+\mathrm{IPA}) / 4\end{array}$} & $\begin{array}{l}\text { IPD }=\text { index for the presence } \\
\text { of the Dengue virus }\end{array}$ & $\begin{array}{l}\text { To identify the presence of Dengue Fever in the } \\
\text { last six months }\end{array}$ & $\begin{array}{l}\text { Yes }=0 \\
\text { No }=1\end{array}$ \\
\hline & & $\begin{array}{l}\text { ICF = index for } \\
\text { Chikungunya fever }\end{array}$ & $\begin{array}{l}\text { To identify the presence of Chikungunya in the } \\
\text { last six months }\end{array}$ & $\begin{array}{l}\text { Yes }=0 \\
\text { No }=1\end{array}$ \\
\hline & & $\begin{array}{l}\text { IPR }=\text { index for the } \\
\text { presence of rats }\end{array}$ & $\begin{array}{l}\text { To identify whether there is presence of rats in } \\
\text { the household }\end{array}$ & $\begin{array}{c}\text { Yes }=0 \\
\text { Rarely }=0.5 \\
\text { No }=1\end{array}$ \\
\hline & & $\begin{array}{l}\text { IPA }=\text { index for the } \\
\text { presence of poisonous } \\
\text { animals }\end{array}$ & $\begin{array}{c}\text { To identify whether there is the presence of } \\
\text { poisonous animals in the household }\end{array}$ & $\begin{array}{c}\text { Yes }=0 \\
\text { Rarely }=0.5 \\
\text { No }=1\end{array}$ \\
\hline \multirow{3}{*}{$\begin{array}{l}\text { Socioeconomic } \\
\text { indicator - } \\
\text { SEI }\end{array}$} & \multirow{3}{*}{$\begin{array}{c}\mathrm{SEI}=(\mathrm{EDI}+\mathrm{FII}+ \\
\mathrm{UEI}) / 3\end{array}$} & EDI $=$ education index & $\begin{array}{l}\text { To identify the level of education of the head of } \\
\text { the family }\end{array}$ & $\begin{array}{c}\text { Illiterate }=0 \\
\text { Literate }=0.4 \\
\text { Elementary }=0.6 \\
\text { High school }=0.8 \\
\text { University education }=1\end{array}$ \\
\hline & & FII = family income index & To identify the family salary range & $\begin{array}{c}\text { Less than } 1 \text { salary }=0 \\
\text { Between } 1 \text { and } 2 \text { salaries }=0.5 \\
\text { Above } 2 \text { salaries }=1\end{array}$ \\
\hline & & $\begin{array}{l}\text { UEI }=\text { unemployment } \\
\text { index }\end{array}$ & $\begin{array}{c}\text { To identify the number of unemployed adults in } \\
\text { the household }\end{array}$ & $\begin{array}{c}\text { None }=1 \\
1 \text { person }=0.5 \\
2 \text { people }=0.4 \\
\text { Above } 2 \text { people }=0\end{array}$ \\
\hline
\end{tabular}


cities. For the computation and tabulation of the data obtained, electronic spreadsheets of the software Excel ${ }^{\circledR}$ were employed. These data were subjected to a descriptive statistical analysis, which determined the mean value, mode, median, variance, and standard deviation for each indicator.

The questionnaire applied was structured, on a nominal scale, with the identification of each sub-indicator of EHIN, based on Menezes (2007), with adaptations performed for the conditions of local sanitation and infrastructure. The size of the statistical population was established in relation to the number of households in each neighborhood, obtained by information provided by the Treasury Department of the municipality registered in the Urban Property Tax.

Following the criteria adopted by Limeira, Silva and Cândido (2010), Nascimento, Figueira and Silva (2013), and Cunha and Silva (2014), the number of interviews was defined based on the plans of sampling and procedures presented by the standards NBR 5426 (ABNT, 1985a) and NBR 5427 (ABNT, 1985b). A total of 20 interviews was performed in neighborhood $A$, and 80 , in neighborhood $B$, from the $3^{\text {rd }}$ to the $24^{\text {th }}$ of June, 2018.

\section{Quality of water analysis}

The procedures for the control and surveillance of the quality of water for human consumption and their potability standards are described in the Consolidation Ordinance No. 5 (BRASIL, 2017b), of September $28^{\text {th }}, 2017$, of the Brazilian Ministry of Health, that establishes acceptable values for bacteriological, organoleptic, physical, and chemical analyses. To compose the sub-indicator of water quality index, water collections were performed in the interviewed households (one per interview), during the period of application of the questionnaire in the neighborhoods (30 samples for neighborhood $A$, and 80 samples for neighborhood $B$ ). The samples were placed in previously sterilized flasks. For determining chlorine, a procedure was performed in loco, at the Laboratory of Environmental Engineering of the Agreste Campus of UFPE, with the help of a color disk kit for visual collimeter, as well as the physicochemical and microbiological analyses of the samples.

Analyses to determine turbidity, color, total, and thermotolerant coliforms were performed. The color analyses were conducted with a UV-VS spectrophotometer (Spectroquant ${ }^{\circledR}$ Pharo 300), whereas the turbidity analyses were performed using the turbidimeter model AQ3010 previously calibrated. The microbiological analyses for the determination of the most probable number (MPN) of total and thermotolerant coliforms were obtained with the Colilert test, approved by the Environmental Protection Agency and included in the Standard Methods for the Examination of Water and Wastewater. The technique of chromogenic substrate was employed, in which the culture medium is hydrolyzed by the specific enzymes of the coliforms and Escherichia coli, whose change in color after the incubation period determines the presence of the pathogen.

\section{Results and Discussion}

The interviews were performed the $3^{\text {rd }}$ to the $24^{\text {th }}$ of June, 2018. The adoption of a questionnaire with objective questions allowed the interviews to be, relatively fast, with a mean time of response of around five minutes.

For the computation and tabulation of the data obtained, and the construction of graphs, electronic spreadsheets from the software Ex$\mathrm{cel}^{\circledR}$ were used. The data used to calculate the second-order indicators were subjected to a descriptive statistical analysis, whose results are presented in Tables 3 and 4. In Figure 2, the conditions of the neighborhoods are shown to be similar, except for those referring to the indices of waste separation (WSI), of poisonous animals (IPA), and of unemployment (UEI). The results and the discussions for each sub-indicator are presented in the following sections.

\section{Indicator for Water Supply}

Both communities presented similar water supply coverage indices. The low values for SCI were expected because the water supply of the city has been intermittent for several years. In 2017, in the peak of the crisis, the state sanitation company (Companhia Pernambucana de Saneamento - Compesa) stipulated a rotation in the supply in which the population of Caruaru received water only seven days per month (SANTANA et al., 2019). The interviews indicated that 95\% of the houses visited in neighborhood $A$ received water from the company once per month.

Among those interviewed, around three fourths of the population reuses water from bath/wash for other purposes. In neighborhood $A$, the main source of drinking/cooking water were trucks with containers $(60 \%)$, whereas in neighborhood $B, 50 \%$ affirmed they bought water from trucks with containers, $43 \%$ used the sealed bottles, $5 \%$ the water from the dealership, and $2 \%$ had artisanal well (Figure 3).

In Table 5, the mean values of the concentration for turbidity parameters, color, and chlorine of the neighborhoods, determined by the laboratory analyses, are presented. The results demonstrated the precariousness of the quality used by inhabitants, the three parameters obtained values below the references established by the Brazilian Ministry of Health (BRASIL, 2017b). In Figure 4, boxplot graphs are presented, representing the distribution of the data observed.

From the analyses performed at the laboratory, $40 \%$ of the samples of neighborhood $A$ presented thermotolerant coliforms, with a mean of 55.30 MPN and standard deviation of 167.22 MPN. In neighborhood $B$, this percentage was $33 \%$, with mean of 38.85 MPN and standard deviation of $146.83 \mathrm{MPN}$. Besides that, $70 \%$ of the samples collected in neighborhood $A$ had total coliforms, whereas in neighborhood $B$ they were $57 \%$. This justifies the score of zero for WQI, since the Consolidation Ordinance No. 5 (BRASIL, 2017b) establishes the absence of total and thermotolerant coliforms as the golden standard. These results can explain the high number of reported cases of diarrhea. In 
2017, neighborhood $A$ registered 712 cases, whereas in neighborhood $B$ they were 3,117 cases (PREFEITURA DE CARUARU, 2018b). The other diseases related to water quality were not relevant to the study, namely: Hepatitis A had only one case notified in 2015, and there were no cases of cholera and schistosomiasis.
Indicator for Sanitary Sewage

For the calculation of the proposed indicator, the presence of a connection of the household to the public sewer network and the presence of a septic tank/sink were considered. In neighborhood $A$, $60 \%$ of the visited houses were connected to the sewer network, and

Table 3 - Results from the $2^{\text {nd }}-$ order indicators for neighborhood $A$, Caruaru City, Pernambuco State, 2018.

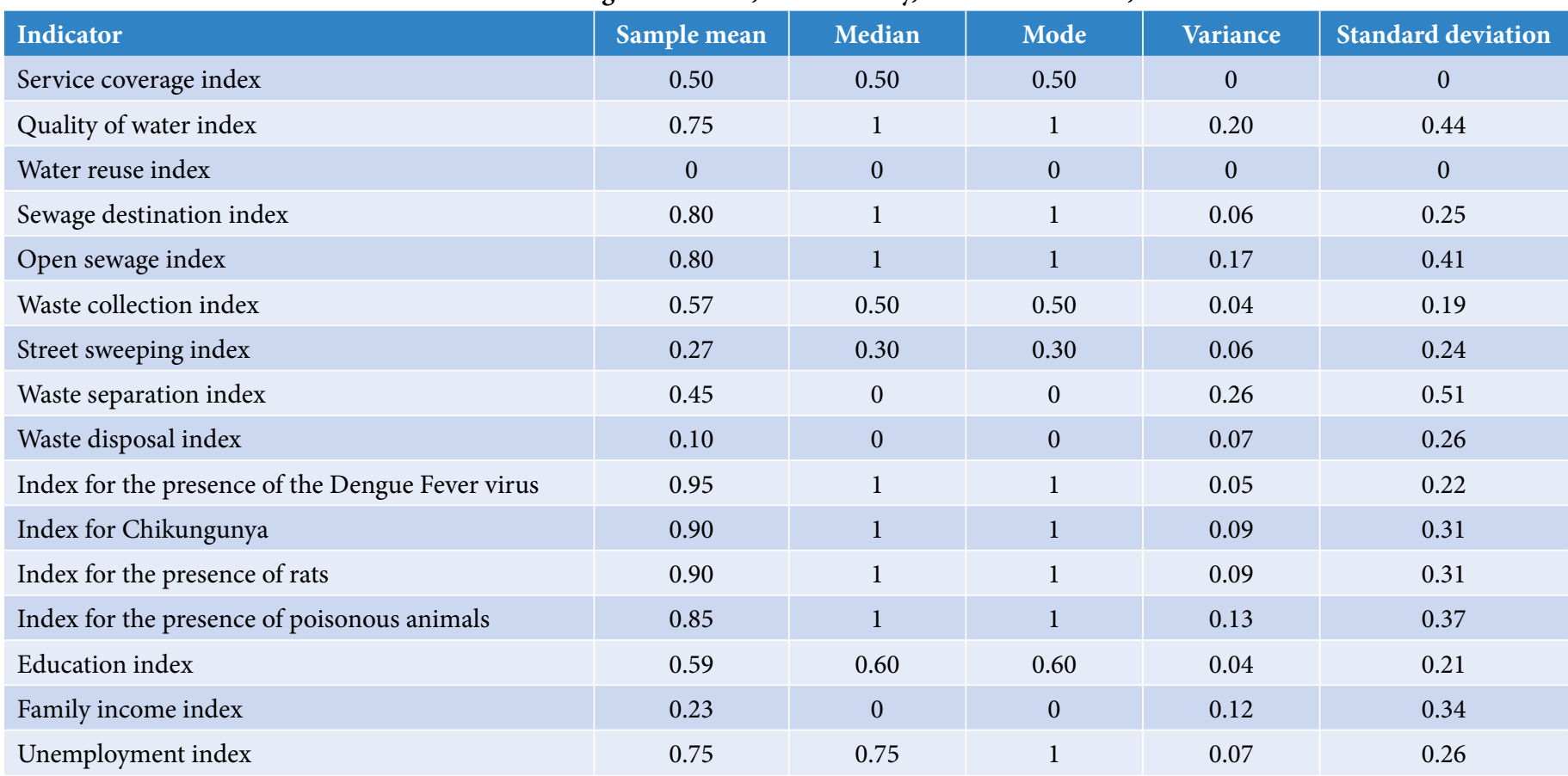

Table 4 - Results from the $2^{\text {nd }}$-order indicators for neighborhood B, Caruaru City, Pernambuco State, 2018.

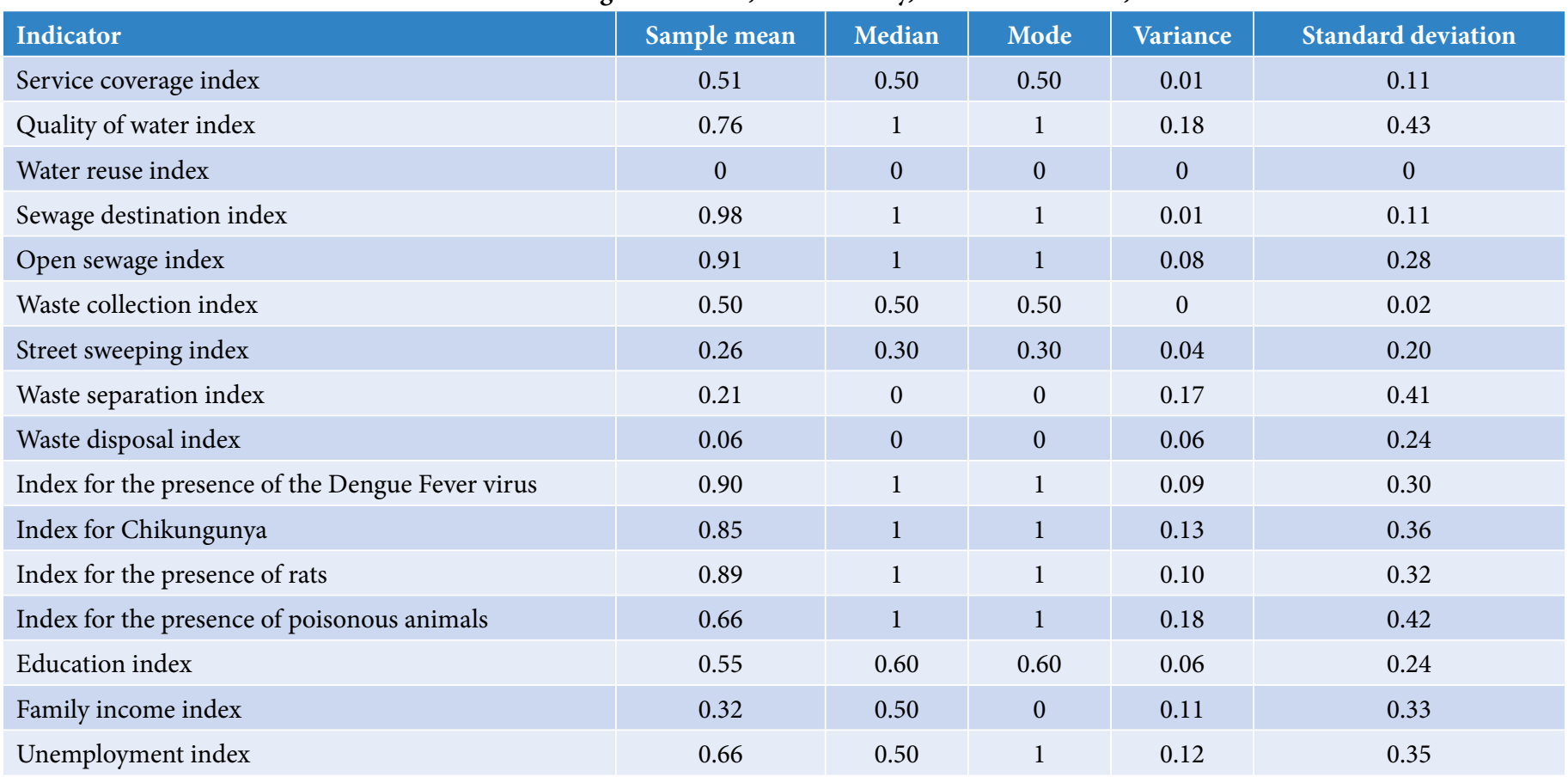


$40 \%$ had septic tank/sink. In certain sections of the neighborhood, a big difference in the sanitary conditions of neighboring blocks was noticed: on one side, healthy conditions and, on the other side, unhealthy conditions. Neighborhood $B$ presented $95 \%$ of the houses connected to the collection network and from them, $5 \%$ affirmed they had septic tank/sink. Therefore, the sub-indicator SDI was equal to 0.80 and 0.98 in neighborhoods $A$ and $B$, respectively.

\section{Indicator for Solid Waste}

The waste collection system in both neighborhoods has a weekly frequency of collection. In neighborhoods $A$ and $B, 80$ and $99 \%$ of the houses were served by the collection system of Caruaru City Hall, respectively. Even with the weekly frequency of waste collection, the population had the habit of disposing of their waste at a time close to the collection, to avoid that animals would touch the bags. Therefore, there was no waste close to households in both neighborhoods. Around 85 and $94 \%$ of households in neighborhoods $A$ and $B$ let their waste on the floor until the moment of collection, respectively. The waste observed in loco derived from building renovations, characterized as civil construction waste, and was found in lands without occupation.

According to the people interviewed, the sweeping of the streets was unsatisfactory, since in neighborhood $A, 55 \%$ of streets in which

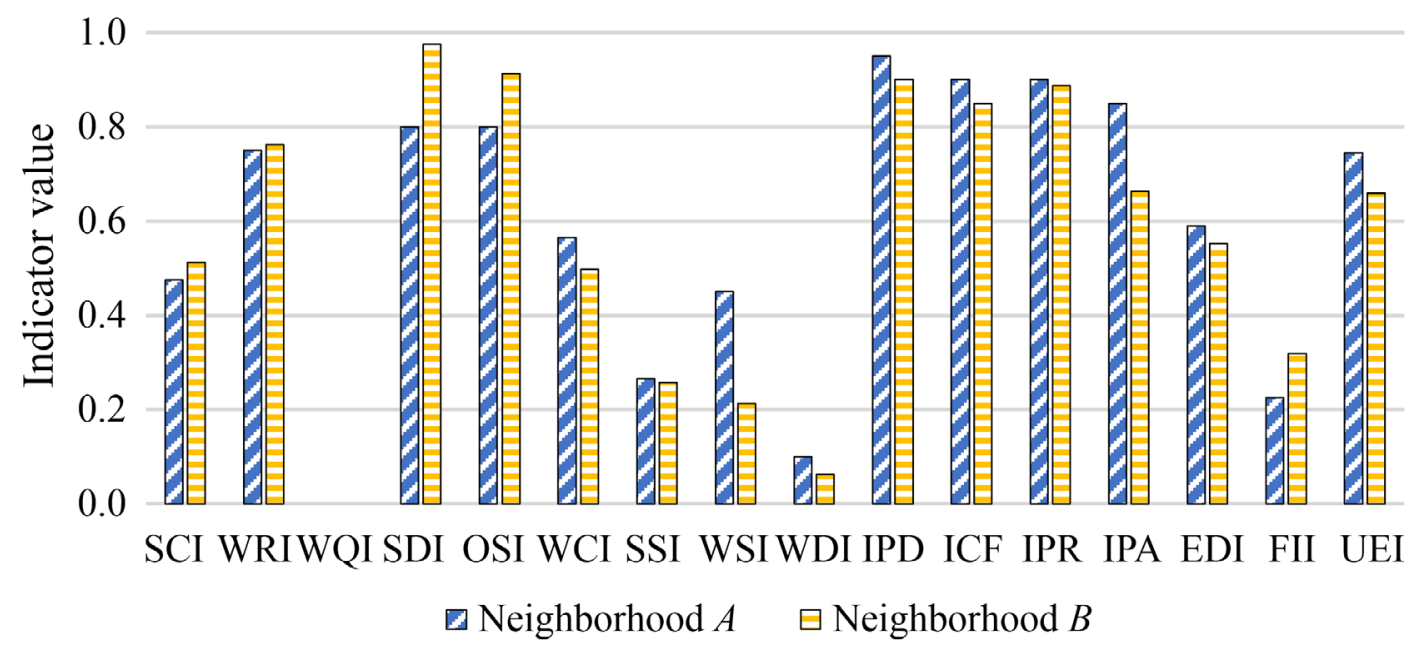

Figure 2 - Second-order indicators for neighborhoods $A$ and B, Caruaru City, Pernambuco State, 2018.

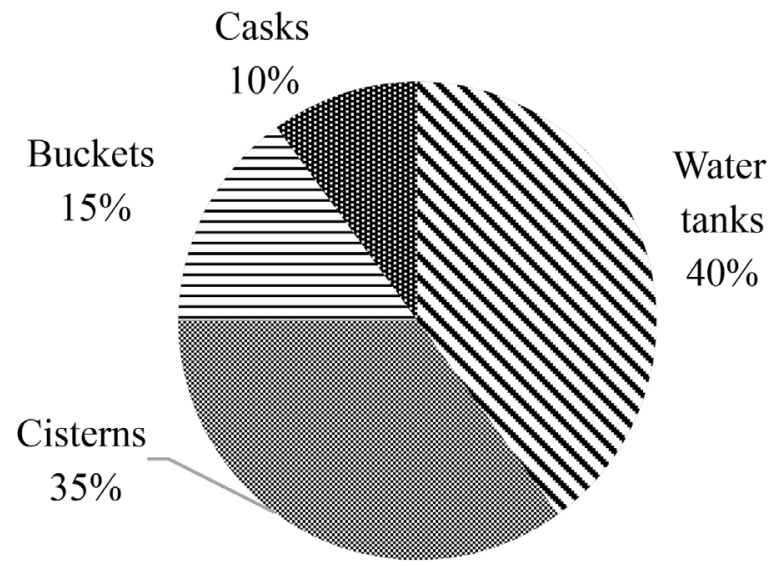

(A)

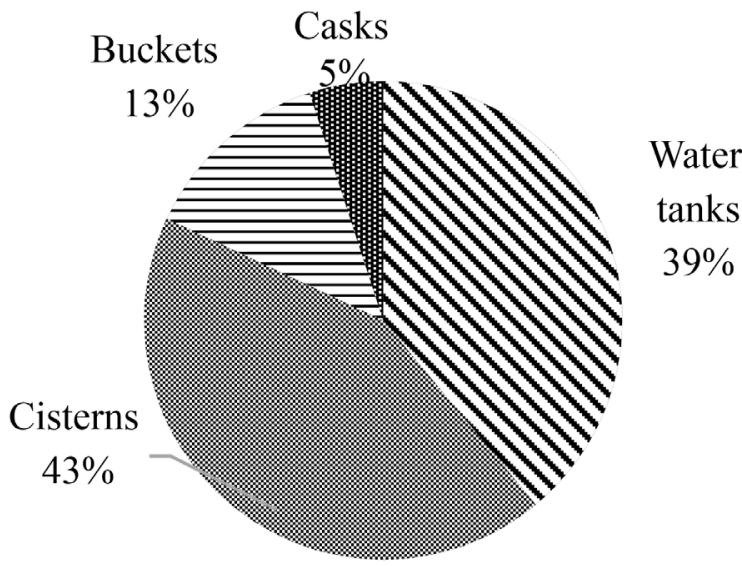

(B)

Figure 3 - Main types of storage: (A) NEIGHBORHOOD $A$ and (B) neighborhood $B$. 
interviews were conducted the service was rarely performed; in neighborhood $B$, it corresponded to $40 \%$. The service was never performed in 30 and $31 \%$ of the streets in neighborhoods $A$ and $B$, respectively. The reports indicated that inhabitants themselves were responsible for sweeping sidewalks. The presence of places with vacant lots and the absence of sweeping and weeding were noticed, factors which provide places favorable to the development of the mosquito responsible for the virus of Dengue Fever and Chikungunya.

Data collection for the determination of ISW indicated the need for the implementation of permanent environmental education programs aiming at population awareness, regarding the disposal of civil construction waste on lands without occupation. A partnership can be established with associations of waste collectors to encourage recycling, besides implementing voluntary delivery points for the population to safely pack the waste. Some neighborhoods in Caruaru have containerization systems to prevent the accumulation of waste on the main roads. This system has been presenting good results, and the protection of garbage from weather variations, odor elimination, and reduction in insect proliferation are among the benefits. The rise in the frequency of sweeping the streets is also indicated to avoid the proliferation of venomous animals and the mosquito that transmits arboviruses.

\section{Indicator for the Control of Vectors}

The vector infection rates in the last six months indicated that the greater proliferation of the mosquito Aedes Aegypti in Caruaru City occurred in neighborhoods $A$ and $B$. These neighborhoods are in the range of high risk of outbreak when 2015 and 2017 are analyzed (PREFEITURA DE CARUARU, 2018a). Given the intermittence in public water supply, the neighborhoods have many household reservoirs (water tanks). Around $40 \%$ of the houses in neighborhood $A$ stored water in water tanks, and in neighborhood $B, 43 \%$ used cisterns. This strategy is used to circumvent the lack of continuous supply, which, according to Fiocruz (2016), contributes to the proliferation of the mosquito that is the vector of the diseases analyzed. Resendes et al. (2010) claim that the association between the risk of Dengue Fever transmission and the social conditions require attention when the municipality is analyzed together with other variables, such as: degree of population immunity, effectiveness of control measures, degree of infestation by the vector, habits and behaviors of the population.

The highest indices of the presence of the virus of Dengue Fever (DENV) were registered in neighborhood $B$. Because of the greater number of inhabitants, there was an increase from 59 cases to 105 , from 2015 to 2016 , and a reduction to 12 cases in 2017. From 2015 to 2016, neighborhood $A$ registered a fall, from 39 cases to 14 , which decreased to 7 confirmed cases

Table 5 - Parameters of water quality in neighborhoods $A$ and $B$, Caruaru-PE, 2018. Sample size: $30($ neighborhood $A)$ and $80($ neighborhood $B)$.

\begin{tabular}{|l|c|c|c|}
\hline Parameter & $\begin{array}{c}\text { Neighborhood } \\
\text { A }\end{array}$ & $\begin{array}{c}\text { Neighborhood } \\
\boldsymbol{B}\end{array}$ & $\begin{array}{c}\text { Reference from the Consolidation Ordinance } \\
\text { No. 5/2017 }\end{array}$ \\
\hline Turbidity (NTU) & 4.61 & 1.06 & Maximum value of $0.5 \mathrm{NTU}$ \\
\hline Color $(\mathrm{uH})$ & 45.45 & 16.55 & Maximum value of $15 \mathrm{uH}$ \\
\hline Chlorine $(\mathrm{mg} / \mathrm{L})$ & 0.36 & 0.76 & Minimum value of $0.5 \mathrm{mg} / \mathrm{L}$ \\
\hline
\end{tabular}

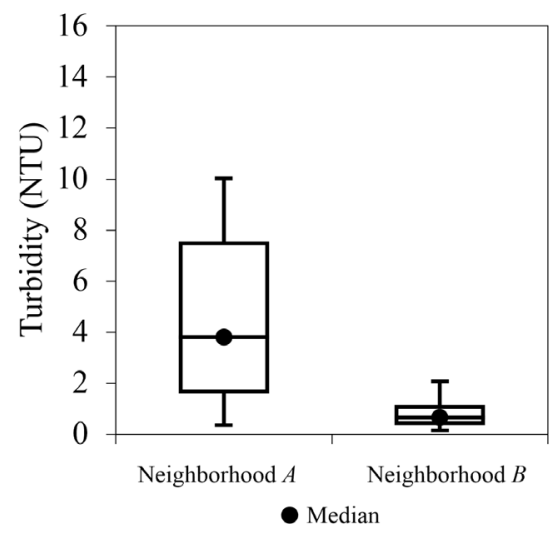

(a) Turbidity (NTU)

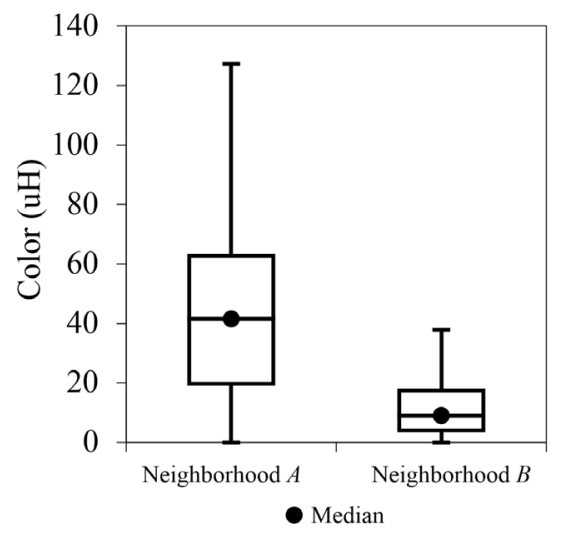

(b) Color $(\mathrm{uH})$

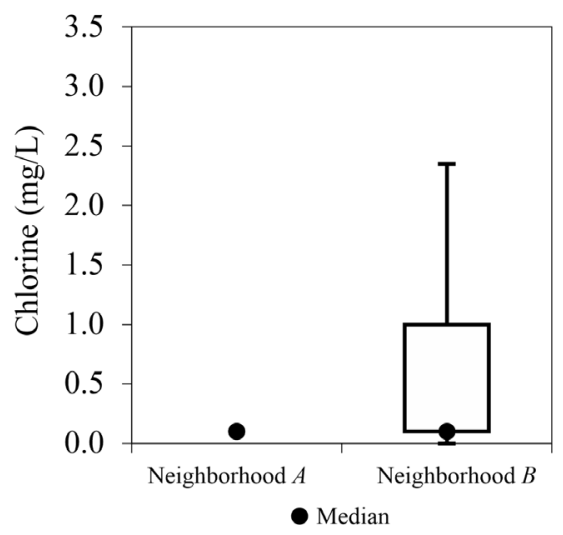

(c) Chlorine $(\mathrm{mg} / \mathrm{L})$

Figure 4 - Distribution of the values of the water quality parameters in neighborhoods A and B. 
in 2017 (PREFEITURA DE CARUARU, 2018a). The fall in the number of cases was also verified in Pernambuco State between 2016 (57,259 cases) and 2017 (7,431 cases) (PREFEITURA DE CARUARU, 2018a). Oliveira et al. (2017) indicate that once the individual is primarily contaminated by the virus of Dengue Fever, a long-term immunity against the same serotype will occur. This suggests the decrease between 2016 and 2017.

The first reports of the virus of Chikungunya in Caruaru City occurred in 2015. In the period of data collection, the neighborhoods registered considerable increments in the rates of the disease during 2015 and 2016, a fact which evidences that several states of the Northeastern region presented Chikungunya fever outbreaks, which shows the increase in 2016 (277,882 probable cases), which were 20,901 cases in the country in 2015 (BRASIL, 2017a). During the research period, neighborhood $A$ registered 44 confirmed cases, whereas neighborhood $B, 47$ (PREFEITURA DE CARUARU, 2018a).

The comparison of the results of the questionnaire application and the confirmed cases by the Caruaru Health Secretariat demonstrates that there is a difference between the understanding of the population and the effective confirmation by the health institution. For instance, there were 800 notified cases of Dengue Fever in Caruaru City in 2017; nevertheless, only 148 were confirmed. Similarly, for Chikungunya, 399 cases were notified, of which only 180 were confirmed. Oliveira et al. (2017) affirmed that the epidemiological data on the diseases caused by the viruses of Dengue Fever and Chikungunya are difficult to interpret, because the Chikungunya virus was not included in the universal notification system, and it also presents similar clinical characteristics in the acute phase.

Silva et al. (2017) conducted the study on the correlation between the environmental health index and indices of diseases related to sanitation services. The comparison was performed among the first-order indices obtained in 18 neighborhoods in the urban area of Maceió City (Alagoas State). With this study, the authors concluded that the major indices were: Dengue Fever, Hepatitis, and Leptospirosis. Nonetheless, when the direct correlation between EHI and the diseases was performed, the results were not satisfactory because of the linking of data between information on health (per neighborhood) and the provision of basic sanitation services (per census sector). The authors emphasized three possible causes for the low correlation: the absence of correlation between EHI and the diseases; spatial resolution determination for the correlation and the conflict between data acquisition by the neighborhoods and IBGE Demographic Census; or the indicators not being satisfactory to represent the reality of the study region.

In neighborhood $A$, only one household reported one confirmed case of Dengue Fever, and two households reported two cases of Chikungunya, whereas in neighborhood $B$, eight residences informed that there were confirmed cases of Dengue Fever, and 24 family members had Chikungunya. In 10 and $12 \%$ of the visited places, there was the presence of standing water close to the household in neighborhoods $A$ and $B$, respectively.

After the analysis of other vectors of diseases, $40 \%$ of the people interviewed from neighborhood $A$ had pets. In this neighborhood, around
$45 \%$ affirmed there was the presence of rats, $90 \%$, of cockroaches, and only $15 \%$, of poisonous animals (snakes, scorpions, etc.). In neighborhood $B, 52 \%$ of households did not have pets, $47 \%$ claimed there was the presence of rats, $64 \%$, of cockroaches, and $24 \%$, of poisonous animals.

\section{Socioeconomic Indicator (SEI)}

When the social aspects were analyzed, the education level, family income, unemployed adults, and the number of residents in the household were considered. $50 \%$ of the people interviewed in neighborhood $B$ had complete elementary school, $23 \%$ had complete high school, and only one person interviewed claimed having higher education. In neighborhood $A$, there was the same number of people interviewed with complete elementary and high school (35\%), and no residents with higher education. Regarding the income per capita, neighborhood $A$ presented the mean value of $\mathrm{R} \$ 507$ per month, whereas neighborhood $B, \mathrm{R} \$ 525$. As to unemployed adults, $45 \%$ of the people interviewed affirmed that there was one adult who was not working in neighborhood $A$, and in $50 \%$ of households, there were no unemployed people. In neighborhood $B, 44 \%$ claimed that only one person was unemployed in their household, and in $46 \%$, there were no unemployed people. Regarding the number of residents, most households had more than two residents, in neighborhood $A(55 \%)$ and in neighbor$\operatorname{hood} B(68 \%)$.

\section{Results of EHIN}

The neighborhoods evaluated were categorized as medium health, according to the range established by Dias, Borja and Moraes (2006), with the values of EHIN equal to 0.56 and 0.57 , for neighborhoods $A$ and $B$, respectively. When the individual analysis of the first-order indicatives was performed (Table 6), both neighborhoods were classified with low health in the indices of water supply and solid waste, demonstrating the deficit in the services offered to cities inhabitants.

The water quality index, whose score was zero for both neighborhoods, is one of the items that demonstrate urgency for interventions from the public sector since it directly affects the population. The results reflect the expressive number of confirmed cases of diarrhea from 2015 to 2017, which suggests a growing trend in both neighborhoods.

Regarding the indicator for solid waste, the indices for street sweeping (SSI) and waste disposal (WDI) presented characteristics of low health. In neighborhood $A$, the waste separation index presented a score of 0.45 , whereas it was 0.21 in neighborhood $B$, which demonstrates that the people interviewed perform the separation in their households, although the public power does not conduct selective collection in the city.

The indicator for the control of vectors, for both neighborhoods, was observed as healthy, considering that the questionnaire referred to sickness in the last six months. Regarding the socioeconomic conditions, a low level of education of respondents was observed and, especially, income per capita below a minimum wage, which reflects in a low score of the socioeconomic indicator. 
Table 6 - Individual score for the indicators of neighborhoods $A$ and B, Caruaru City, Pernambuco State, 2018.

\begin{tabular}{|l|c|c|c|}
\hline \multirow{2}{*}{\multicolumn{1}{c}{ Indicator }} & \multicolumn{2}{|c|}{ Individual score } & Salubrity \\
\cline { 2 - 4 } & Neighborhood $\boldsymbol{A}$ & Neighborhood $\boldsymbol{B}$ & Low salubrity \\
\hline Indicator for water supply & 0.41 & 0.43 & Healthy \\
\hline Indicator for sanitary sewage & 0.80 & 0.94 & Low salubrity \\
\hline Indicator for solid waste & 0.35 & 0.26 & Healthy \\
\hline Indicator for the control of vectors & 0.90 & 0.51 & Medium salubrity \\
\hline Socioeconomic indicator & 0.52 & & . \\
\hline
\end{tabular}

\section{Final Considerations}

The success of implementing public policies is directly related to the management capacity of the institutions, the strategies adopted, the budgetary and financial availability, and managers' support to the actions. In this context, the Environmental Health Indicator for Neighborhoods (EHIN) is an instrument of environmental planning and management to help public policies, which can guide the actions of public managers and the civil society.

Based on information obtained in loco and the water quality analyses, both neighborhoods evaluated presented characteristics of medium health. The results demonstrated that the assessment of water supply, solid waste, and socioeconomic indices require a greater attention and priority from public policies. The adoption, of actions directed to the improvement of water supply, particularly regarding the quantity and quality of water available to the population, is suggested. The quality of water consumed is low, because the population uses alternative sources for water consumption. The role of the institutions of the civil society to change the scenario described by research is highlighted, by population awareness and adoption of practices such as recycling, water reuse, among others.
EHIN presented satisfactory results and reflected the reality of the neighborhoods evaluated. It is an efficient management tool for the decision-making of public managers because it established technical criteria to prioritize sectors with worse environmental and housing conditions. Furthermore, EHIN is an efficient tool for the planning and management of structural and non-structural actions of environmental sanitation in the urban network. Integrated public policies can be formulated from the factors identified as unhealthy by the indicators in this study. Therefore, this indicator is expected to be adopted in the evaluation of environmental health of neighborhoods, initially for any Brazilian city, since the determination of the sub-indicators is based only on interviews, and in the laboratory analysis of color, turbidity, and chlorine concentration in the water.

\section{Acknowledgements}

The authors acknowledge the financial support given by Foundation for the Support of Science and Technology of Pernambuco (Fundação de Amparo à Ciência e Tecnologia de Pernambuco, FACEPE) (Brazil) [process IBPG-0779-3.01/16] and the Coordination for the Improvement of Higher Education Personnel (Coordenação de Aperfeiçoamento de Pessoal de Nível Superior - CAPES) (Brazil) [Finance Code 001].

\section{Contribution of authors:}

Duarte, A.: Conceptualization, Methodology, Validation, Formal analysis, Investigation, Data curation, Writing — original draft, Writing - review \& editing. Bezerra, S.: Conceptualization, Methodology, Validation, Formal analysis, Investigation, Writing — review \& editing, Supervision, Project administration. Gonçalves, E.: Conceptualization, Methodology, Validation, Formal analysis, Writing — review \& editing.

\section{References}

ASSOCIAÇÃO BRASILEIRA DE NORMAS TÉCNICAS (ABNT). NBR 5426

- Planos de amostragem e procedimentos na inspeção por atributos. Rio de Janeiro: ABNT, 1985a.

ASSOCIAÇ̃̃O BRASILEIRA DE NORMAS TÉCNICAS (ABNT). NBR 5427 - Guia para a utilização da norma NBR 5426 - Planos de amostragem e procedimentos na inspeção por atributos. Rio de Janeiro: ABNT, 1985b.

BARRETO, J. B.; FEITOSA, P. H. C.; ANJOS, K. L.; TEIXEIRA, R. O. Criação de um modelo de indicador de salubridade ambiental (EHI) adaptado ao contexto de municípios de pequeno porte (EHI/MPP). Revista IberoAmericana de Ciências Ambientais, n. 11, v. 2, p. 278-295, 2020. https://doi. org/10.6008/CBPC2179-6858.2020.002.0028

BELIZÁRIO, F. (org.). Reflexão e práticas em educação ambiental: discutindo o consumo e a geração de resíduos. São Paulo: Oficina de Textos, 2012.

BOSCO, R. B.; CARDOSO, A. O.; YOUNG, A. F. Aplicação de análise multivariada para a construção de indicadores ambientais na relação entre precipitação e deslizamentos. Revista Brasileira de Ciências 
Ambientais, n. 52, p. 44-61, 2019. https://doi.org/10.5327/Z2176947820190471

BRASIL. Lei $\mathrm{n}^{\circ}$ 11.445, de 5 de janeiro de 2007: Estabelece diretrizes nacionais para o saneamento básico. Diário Oficial da União, 2007. Available at: <http:// www.planalto.gov.br/ccivil_03/_ato2007-2010/2007/lei/111445.htm>. Accessed on: Jan 2018.

BRASIL. Ministério da Saúde. Monitoramento dos casos de dengue, febre Chikungunya e febre pelo vírus Zika até a semana epidemiológica. Boletim Epidemiológico 33, v. 48, n. 27, 2017b.

BRASIL. Ministério da Saúde. Portaria de Consolidação no ${ }^{\circ}$, de 29 de setembro de 2017. Consolidação das normas sobre a saúde do Sistema Único de Saúde. Brasília, 2017c.

CONSELHO ESTADUAL DE SANEAMENTO (CONESAN). Secretaria de Recursos Hídricos e Saneamento e Obras. Manual de Salubridade Ambiental EHI. São Paulo: Secretaria de Recursos Hídricos e Saneamento e Obras, 1999.

CUNHA, T. B.; SILVA, T. C. Indicadores como suporte para gestão na subbacia hidrográfica do rio verde. Caderno Prudentino de Geografia, Presidente Prudente, v. 1, n. 36, p. 228-240, 2014.

DIAS, M.; BORJA, P. C.; MORAES, L. R. S. Índice de salubridad ambiental en áreas con ocupaciones espontáneas: Un estudio en Salvador, Bahia, Brasil. Ingeniería Sanitaria y Ambiental, n. 86, p. 62-66, 2006.

FUNDAÇÃO OSWALDO CRUZ (FIOCRUZ). Conheça o comportamento do mosquito Aedes aegypti e entenda a razão que leva este pequeno inseto a ser taxado desta forma. FIOCRUZ, 2016. Available at: <http://www.ioc.fiocruz.br/ dengue/textos/oportunista.html>. Accessed on: Jul. 2018.

INSTITUTO BRASILEIRO DE GEOGRAFIA E ESTATÍSTICA (IBGE). Censo demográfico: Cidades 2010. IBGE. Available at: <https://cidades.ibge.gov.br $>$. Accessed on: Oct. 2017.

KOBREN, J. C. P.; SANTOS, L. N.; CRUZ, P. A. G.; REZENDE, T. C.; BARBADO, N. Aplicação do Indicador de Salubridade Ambiental (EHI) no Município de Porto Rico, PR. Mundi Meio Ambiente e Agrárias, v. 4, n. 1, 2019

LI, G.; WENG, Q. Measuring the quality of life in city of Indianapolis by integration of remote sensing and census data. International Journal of Remote Sensing, v. 28, n. 2, p. 249-267, 2007. https://doi. org/10.1080/01431160600735624

LIMEIRA, M. C. M.; SILVA, T. C.; CÂNDIDO, G. A. Gestão adaptativa e sustentável para a restauração de rios: Parte II - O tema desenho do programa de capacitação social. Revista Brasileira de Recursos Hídricos, v. 15, n. 1, p. 17 26, 2010. https://doi.org/10.21168/rbrh.v15n1

LUCK, M.; WU, J. A. Gradient analysis of the landscape pattern of urbanization in the Phoenix metropolitan area of USA. Landscape Ecology, v. 17, p. 327-339, 2002. https://doi.org/10.1023/A:1020512723753

MARI, A. C. C.; KORBER, L. P. P.; MARI JUNIOR, A.; DIERINGS, L.; FRIGO, E. P. Indicador de Salubridade Ambiental de municípios lindeiros e não lindeiros da Bacia Hidrográfica do Paraná III. Ambiência, v. 15, n. 1, p. 57-72, 2019. https://doi.org/10.5935/ambiencia.2019.01.04

MENDONÇA, M. H. M.; ROSENO, S. A. M.; CACHOEIRA, T. R. L.; SILVA, Á. F. S.; JÁCOME, P. R. L. D. A.; JÁCOME JÚNIOR, A. T. Bacteriological analysis of drinking water sold by water tank trucks. Revista Ambiente \& Água, v. 12, n. 3, p. 468-475, 2017. https://doi.org/10.4136/ambi-agua.1934

MENEZES, G. O. Aplicação do índice de salubridade ambiental em comunidades carentes e sua comparação com comunidades padrão: Instrumento para planos de gestão municipal. Dissertação (Mestrado em Engenharia Ambiental) - Universidade Federal de Ouro Preto, Ouro Preto, 2007.
MUSSE, M. A.; BARONA, D. A.; RODRIGUEZ, L. M. Urban environmental quality assessment using remote sensing and census data. International Journal of Applied Earth Observation and Geoinformation, v. 71, p. 95-108, 2018. https://doi.org/10.1016/j.jag.2018.05.010

NASCIMENTO, M. O. T.; FIGUEIRA, H. J. A.; SILVA, T. C. Metodologia para priorização de ações em aglomerados subnormais considerando os riscos de deslizamentos e inundações e as condições de moradia. Engenharia Sanitária e Ambiental, v. 18, n. 1, p. 9-46, 2013. https://doi.org/10.1590/S141341522013000100005

OLIVEIRA, W. K.; FRANÇA, G. V. A.; CARMO, E. H.; DUNCAN, B. B.; KUCHENBECKE, R. S.; SCHMIDT, M. I. Infection-related microcephaly after the 2015 and 2016 Zika virus outbreaks in Brazil: a surveillance-based analysis. The Lancet, v. 390, n. 10097, p. 861-870, 2017. https://doi.org/10.1016/S01406736(17)31368-5

\section{ORGANISATION FOR ECONOMIC CO-OPERATION AND} DEVELOPMENT (OECD). OECD core set of indicators for environmental performance reviews. Paris: OECD, 1993.

PADILLA, C. M.; KIHAL-TALANTIKIT, W.; PEREZ, S.; DEGUEN, S. Use of geographic indicators of healthcare, environment and socioeconomic factors to characterize environmental health disparities. Environmental Health, v. 15, n. 1, 2016. https://doi.org/10.1186/s12940-016-0163-7

PEIXOTO, F. S.; FELIX NETO, J. M.; GOMES, I. N.; DIAS, G. H. Índice de saneamento ambiental da área urbana do município de Mossoró-RN. Revista Brasileira de Geografia Física, v. 11, n. 6, p. 2130-2139, 2018. https://doi. org/10.26848/rbgf.v11.6.p2130-2139

PREFEITURA DE CARUARU. Gerência de Gestão do Trabalho e Educação em Saúde. Relatório do número de casos confirmados de Dengue, Febre Chikungunya e Leptospirose. Caruaru: Prefeitura de Caruaru, 2018a.

PREFEITURA DE CARUARU. Gerência de Gestão do Trabalho e Educação em Saúde. Relatório do número de casos confirmados de diarreia. Caruaru: Prefeitura de Caruaru, 2018b.

RESENDES, A. P. C.; SILVEIRA, N. A. P. R.; SABROZA, P. C.; SANTOS, R. S. Determinação de áreas prioritárias para ações de controle da Dengue. Revista de Saúde Pública, São Paulo, v. 44, n. 2, p. 274-282, 2010. https://doi. org/10.1590/S0034-89102010000200007

ROCHA, L. A.; RUFINO, I. A. A.; BARROS FILHO, M. N. M. Indicador de salubridade ambiental para Campina Grande, PB: adaptações, desenvolvimentos e aplicações. Engenharia Sanitária e Ambiental, v. 24, n. 2, p. 315-326, 2019. https://doi.org/10.1590/s1413-41522019166209

SANTANA, R. A.; BEZERRA, S. T. M.; SANTOS, S. M.; COUTINHO, A. P.; COELHO, I; C.; PESSOA, R. V. S. Assessing alternatives for meeting water demand: A case study of water resource management in the Brazilian Semiarid region. Utilities Policy, v. 61, p. 100974, 2019. https://doi.org/10.1016/j. jup.2019.100974

SANTOS, L. P.; FORMIGA, K. M.; FERREIRA, N. Construção de um indicador socioambiental e a relação com o sistema de drenagem urbana. Revista Brasileira de Ciências Ambientais, v. 55, n. 2, p. 171-191, 2020. https:// doi.org/10.5327/Z2176-947820200638

SANTOS, R. S. F.; FERREIRA, M. I. P. Indicadores e índices de salubridade ambiental aplicados a regiões estuarinas: o caso da comunidade de Gargaú, São Francisco do Itabapoana/RJ. Boletim do Observatório Ambiental Alberto Ribeiro Lamego, v. 10, n. 1, p. 139-164, 2016. https://doi.org/10.19180/21774560.v10n12016p139-164

SILVA, S. D. A.; GAMA, J. A. D. S.; CALLADO, N. H.; SOUZA, V. C. B. D. Sanitation and public health in the hydrographic basin of Reginaldo creek, 
Maceió, Alagoas. Engenharia Sanitária e Ambiental, v. 22, n. 4, p. 699-709, 2017. https://doi.org/10.1590/s1413-41522017146971

TAYRA, F.; RIBEIRO, H. Modelos de indicadores de sustentabilidade: síntese e avaliação crítica das principais experiências. Saúde e Sociedade, v. 15, n. 1, p. 84-95, 2006. https://doi.org/10.1590/S0104-12902006000100009

TEIXEIRA, D. A.; PRADO FILHO, J. F.; SANTIAGO, A. F. Indicador de salubridade ambiental: Variações da formulação e usos do indicador no Brasil. Engenharia Sanitária e Ambiental, v. 23, n. 3, p. 543-556, 2018. https://doi. org/10.1590/s1413-41522018170866
VALVASSORI, M.; ALEXANDRE, N. Aplicação do Indicador de Salubridade Ambiental (EHI) para áreas urbanas. Revista Brasileira de Ciências Ambientais, n. 25, p. 1-19, 2012.

WORLD HEALTH ORGANIZATION (WHO). Fact sheet on sanitation. Geneva: WHO, 2015. Available at: <http://www.who.int $>$. Accessed on: Jan. 2018.

WU, J.; JENERETTE, G. D.; BUYANTUYEV, A.; REDMAN, C. L. Quantifying spatiotemporal patterns of urbanization: The case of the two fastest growing metropolitan regions in the United States. Ecological Complexity, v. 8, n. 1, p. 1-8, 2011. https://doi.org/10.1016/j.ecocom.2010.03.002 